\title{
PENGARUH GAYA MENGAJAR DAN MOTIVASI BELAJAR TERHADAP HASIL BELAJAR STUT SENAM LANTAI
}

\author{
Fegie Rizkia Mulyana \\ Universitas Siliwangi \\ Email: fegierizkiamulyana@gmail.com
}

\begin{abstract}
ABSTRAK
Tujuan penelitian ini adalah untuk memperoleh informasi tentang pengaruhnya gaya mengajar dan motivasi belajar terhadap hasil belajar stut senam lantai mahasiswa PJKR Universitas Siliwangi Kota Tasikmalaya. Teknik analisis menggunakan analisis variansi (ANAVA) dua jalur, dilanjutkan dengan Uji Tukey pada taraf signifikansi $\alpha=0,05$. Diperoleh :(1) Secara keseluruhan hasil belajar stut yang diajar dengan gaya mengajar komando lebih baik daripada yang diajar dengan gaya mengajar latihan $(\mathrm{Fo}=20,7353>\mathrm{Ft}=4,11) ;(2)$ terdapat interaksi antara gaya mengajar dengan motivasi belajar terhadap hasil belajar stut, Fo $=6,5253>\mathrm{Ft}=$ 4,11. (3) bagi mahasiswa yang memiliki motivasi belajar tinggi, hasil belajar stut yang diajar dengan gaya mengajar komando lebih baik dibandingkan dengan mahasiswa yang diajar dengan gaya mengajar latihan ( $\mathrm{qo}=3,100>\mathrm{qt}=3,63)$; (4) bagi mahasiswa yang memiliki motivasi belajar rendah hasil belajar stut yang diajar dengan gaya mengajar komando lebih baik daripada yang diajar dengan gaya mengajar latihan $(\mathrm{q} 0=14,22<\mathrm{qt}=3,63)$. Diharapkan kepada seluruh dosen dan guru dalam memberikan pembelajaran olahraga khususnya matakuliah senam lantai lebih baik menggunakan gaya mengajar komando.
\end{abstract}

Kata Kunci : Gaya Mengajar, Motivasi Belajar, Hasil Belajar Stut Senam Lantai

\begin{abstract}
The purpose of this study was to obtain information about the influence of style of teaching and learning motivation towards learning outcomes stut gymnastics floor student PJKR Siliwangi University town of Tasikmalaya. Analysis techniques using variansi analysis (ANAVA) two lines, followed by the Tukey Test at significance level $\alpha=0.05$. Retrieved : (1) overall learning outcomes stut taught by a teaching style better command than he was taught the style of teaching exercises $(\mathrm{Fo}=20.7353>\mathrm{Ft}=4.11)$; (2) there is an interaction between the style of teaching with learning motivation towards learning outcomes stut, $\mathrm{Fo}=6.5253>\mathrm{Ft}=4.11$, (3) for students who have a high learning motivation, learning outcomes stut taught by a teaching style command better than the students who were taught by a teaching style exercises (qo = $3.100 \mathrm{qt}>=3.63$ ); (4) for students who have a low learning outcomes learning motivation stut taught by a teaching style better command than he was taught the style of teaching exercises (q0 $=<14.22 \mathrm{qt}=3.63$ ). Expected to all lecturers and teachers in providing learning sports especially matakuliah floor is better to use a teaching style of command.
\end{abstract}

Keywords : A Style Of Teaching, Learning Motivation, Learning Outcomes Stut Gymnastics Floor

\section{PENDAHULUAN}

Dewasa ini olahraga telah berkembang menjadi fenomena sosial yang tersebar di seluruh dunia. Terkait dengan perkembangan olahraga, olahraga Senam yang dikenal dalam bahasa Indonesia sebagai salah satu cabang olahraga, merupakan terjemahan 
langsung dari bahasa Inggris atau gymnastics merupakan serapan kata dari bahasa Yunani Gymnos yang berarti telanjang, atau Belanda Gymnastiek.

Menurut Imam Hidayat (2006), Senam adalah latihan tubuh yang dipilih dan dikonstruk dengan sengaja, dilakukan secara sadar dan berencana, disusun secara sistematis dengan tujuan meningkatkan kesegaran jasmani, mengembangkan keterampilan, dan menanamkan nilai-nilai mental spiritual. Sedangkan menurut Werner (2012) "gymnastic may be globally defined as any physical exercise on the floor or apparratus that promotes endurance, strength, flexibility, agility, coordination, and body control." Secara umum senam dapat diartikan sebagai bentuk latihan tubuh pada lantai atau pada alat yang dirancang untuk meningkatkan daya tahan, kekuatan, kelentukan, kelincahan, koordinasi serta kontrol tubuh.

Rendahnya hasil belajar senam mahasiswa PJKR Universitas Siliwangi Kota Tasikmalaya, diduga karena beberapa hal. Pertama karena faktor internal peserta didik seperti kurangnya bakat yang dimiliki, lemahnya motivasi belajar, serta sikap negatif terhadap program pembelajaran yang ditawarkan. Kedua, faktor eksternal, seperti rendahnya kualitas tenaga pengajar/dosen, minimnya sarana belajar, kurangnya dukungan orang tua, terbatasnya dana yang dimiliki atau bahkan lemahnya perhatian pemerintah. Efektifitas dan efisiensi pembelajaran juga terkait dengan masalah dorongan atau minat yang timbul dari diri mahasiswa itu sendiri. Motivasi belajar merupakan faktor psikis yang bersifat non intelektual. Peranannya yang khas adalah dalam hal penumbuhan gairah merasa senang dan semangat untuk belajar. Hal ini sejalan dengan pendapat Mc. Donald dalam Djamarah (2011:148) "motivasi adalah suatu perubahan energi didalam pribadi seseorang yang ditanai dengan timbulnya afekttif (perasaan) dan reaksi untuk mencapai tujuan."

Motivasi belajar adalah suatu dorongan secara psikologis yang dapat mempengaruhi diri seseorang untuk melakukan pembelajaran keterampilan stut dengan baik dan benar sehingga dapat mencapai hasil belajar stut yang baik dan benar secara optimal. Oleh karena itulah untuk mengakomodir adanya perbedaan individual pada diri mahasiswa, penulis memasukkan motivasi belajar sebagai variabel atribut dalam penelitian ini. Atas dasar pemikiran itulah maka penulis tertarik untuk ikut berpartisipasi memecahkan persoalan diatas, melalui penelitian yang berjudul "Pengaruh Gaya Mengajar dan Motivasi Belajar terhadap Hasil Belajar Stut Senam Lantai.“

Rumusan masalah pada penelitian ini adalah (1). keseluruhan, apakah gaya mengajar komando dan gaya mengajar latihan memberikan pengaruh yang berbeda terhadap hasil belajar stut? (2). Apakah terdapat interaksi antara gaya mengajar dengan motivasi belajar terhadap hasil belajar stut? (3). Apakah gaya mengajar komando dan gaya mengajar latihan memberikan pengaruh yang berbeda terhadap hasil belajar stut bagi mahasiswa yang memiliki motivasi belajar tinggi? (4). Apakah gaya mengajar komando dan gaya mengajar latihan memberikan pengaruh yang berbeda terhadap hasil belajar stut bagi mahasiswa yang memiliki motivasi belajar rendah?

Adapun tujuan dari penelitian ini yaitu untuk mengetahui : (1) pengaruh gaya mengajar komando dan latihan terhadap hasil belajar stut, (2) interaksi antara gaya mengajar dan motivasi belajar terhadap hasil belajar stut, (3) pengaruh gaya mengajar komando dan latihan terhadap mahasiswa yang memiliki motivasi belajar tinggi, (4) pengaruh gaya mengajar komando dan latihan terhadap mahasiswa yang memiliki motivasi belajar rendah. 
Menurut Hamalik (2008) hasil belajar adalah "sebagai terjadinya perubahan tingkah laku pada diri seseorang yang dapat diamati dan diukur bentuk pengetahuan, sikap, dan keterampilan.

Mosston (2010:3) berpendapat bahwa "strategi pembelajaran seperti halnya strategi perang, merupakan suatu cara untuk menyiasati sistem pembelajaran, sehingga tujuan proses pembelajaran dapat tercapai dengan efektif dan efisien." Lebih lanjut Mosston mengemukakan gaya mengajar adalah pedoman khusus untuk struktur episode belajar atau pembelajaran. Mosston beranggapan bahwa mengajar adalah serangkaian hubungan yang berkesinambungan antara guru dengan siswa, yaitu: 1) mencoba mencapai keserasian antara apa yang diniatkan dengan apa yang sebenarnya terjadi. maksud $=$ perbuatan $($ intent $=$ action $) .2$ ) masalah yang bertentangan tentang metode mangajar.

Gaya komando adalah pendekatan mengajar yang paling bergantung pada guru. Tujuannya adalah penampilan yang cermat. Menurut Husdarta (2010:31) "Gaya ini bertujuan mengarahkan mahasiswa dalam melakukan tugas gerak secara akurat dan di dalam waktu yang singkat". Siswa harus mengikuti segala intruksi yang disampaikan oleh guru. Sejalan dengan pendapat diatas Lutan (2000) menerangkan bahwa gaya komando adalah pendekatan mengajar yang paling bergantung pada guru.

Gaya mengajar latihan merupakan salah satu model pengajaran yang cocok diterapkan pada perkuliahan gerak, karena memiliki keunggulan sebagai berikut: (1) dosen akan mempunyai peluang untuk mengajar dalam jumlah mahasiswa yang banyak sekaligus, (2) mahasiswa belajar untuk bisa bekerja secara mandiri, (3) mahasiswa mempelajari atas keputusan yang sesuai dengan ketentuan yang ada, (4) mahasiswa belajar mengenai keterbatasan waktu, (5) mahasiswa bisa belajar mengenal sasaran yang harus dicapai dengan melaksanakan tugas-tugas tertentu, (6) mahasiswa memiliki kesempatan untuk meningkatkan interaksi individual dengan setiap mahasiswa.

\section{METODE PENELITIAN}

Metode yang digunakan dalam penelitian ini adalah metode eksperimen. Adapun desain penelitian yang digunakan adalah Faktorial Treatment by Level 2 x 2. Adapun rancangan penelitiannya seperti terlihat pada tabel di bawah ini.

Tabel 1. Desain Treatment by Level 2 × 2

\begin{tabular}{|c|c|c|}
\hline \multirow[b]{2}{*}{ Motivasi Belajar } & \multicolumn{2}{|c|}{ Gaya Mengajar } \\
\hline & $\begin{array}{l}\text { Gaya mengajar } \\
\text { Komando }\left(\mathrm{A}_{1}\right)\end{array}$ & $\begin{array}{l}\text { Gaya Mengajar Latihan } \\
\left(\mathbf{A}_{2}\right)\end{array}$ \\
\hline $\begin{array}{l}\text { Motivasi Belajar Tinggi } \\
\mathrm{B}_{1}\end{array}$ & $\mathrm{~A}_{1} \mathrm{~B}_{1}$ & $\mathrm{~A}_{2} \mathrm{~B}_{1}$ \\
\hline $\begin{array}{l}\text { Motivasi Belajar Rendah } \\
\mathrm{B}_{2}\end{array}$ & $\mathrm{~A}_{1} \mathrm{~B}_{2}$ & $\mathrm{~A}_{2} \mathrm{~B}_{2}$ \\
\hline TOTAL & $\mathrm{A}_{1}$ & $\mathrm{~A}_{2}$ \\
\hline
\end{tabular}

Keterangan :

$\mathrm{A}_{1} \quad$ : Gaya mengajar komando

$\mathrm{A}_{2} \quad$ : Gaya mengajar latihan

$\mathrm{A}_{1} \mathrm{~B}_{1} \quad$ : Gaya mengajar komando dengan motivasi tinggi 
$\mathrm{A}_{2} \mathrm{~B}_{1} \quad$ : Gaya mengajar latihan dengan motivasi tinggi

$\mathrm{A}_{1} \mathrm{~B}_{2} \quad$ : Gaya mengajar komando dengan motivasi rendah

$\mathrm{A}_{2} \mathrm{~B}_{2} \quad$ : Gaya mengajar latihan dengan motivasi rendah

Teknik pengambilan sampel yang digunakan mengacu pada prosedur yang dinyatakan oleh Ferducci (1980) yaitu menetapkan sampel dengan teknik persentase melalui pembagian dengan sistem ranking menggunakan random sampling (acak sederhana). Instrumen penelitian yang digunakan untuk memperoleh data tentang hasil belajar stut adalah tes yang dibuat sendiri oleh peneliti yang berbentuk rubrik penilaian. Mengukur tingkat validitas instrumen ini melalui pernyataan dari yang ahli dalam olahraga senam lantai. Sedangkan mengukur reliabilitas melalui tes-retest (tes dua kali) dan diperoleh nilai $\mathrm{r}=0,92$ (kategori sangat tinggi). Teknik analis data yaitu menggunakan analis variansi (ANAVA) dua jalur, kemudian dilanjutkan dengan Uji Tukey. Sebelumnya harus menguji dulu persyartan analisis yakni uji normalitas dan uji homogenitas.

\section{HASIL DAN PEMBAHASAN}

Untuk menguji hipotesis, data hasil belajar stut diolah dengan menggunakan teknik analisis statistik, yaitu analisis varians (ANAVA) dua jalan. Sebelum data dianalisis, maka terlebih dahulu dilakukan uji persyaratan Anava, yaitu : (1) Uji normalitas, dan (2) Uji homogenitas. Uji normalitas dilakukan pada semua kelompok yang akan dibandingkan dengan menggunakan uji Lilliefors. Hasil pengujian tersebut menunjukkan bahwa harga $\mathrm{L}_{\text {hitung }}$ untuk semua kelompok lebih kecil daripada $\mathrm{L}_{\text {tabel }}$.

Tabel 2. Rangkuman Hasil Uji Normalitas Populasi

\begin{tabular}{ccccc}
\hline Kelompok & $\mathbf{n}$ & $\mathbf{L}_{\text {hitung }}$ & $\begin{array}{c}\mathbf{L}_{\text {tabel }} \\
\mathbf{\alpha = 0 , 0 5}\end{array}$ & Kesimpulan \\
\hline 1 & 20 & 0,1590 & 0,19 & Normal \\
\hline 2 & 20 & 0,1054 & 0,19 & Normal \\
\hline 3 & 20 & 0,1111 & 0,19 & Normal \\
\hline 4 & 20 & 0,1255 & 0,19 & Normal \\
\hline 5 & 10 & 0,1578 & 0,258 & Normal \\
\hline 6 & 10 & 0,1279 & 0,258 & Normal \\
\hline 7 & 10 & 0,1880 & 0,258 & Normal \\
\hline 8 & 10 & 0,0664 & 0,258 & Normal \\
\hline
\end{tabular}

\section{Keterangan :}

Kelompok $1=$ Kelompok mahasiswa yang diajar dengan gaya mengajar resiprokal secara keseluruhan

Kelompok 2 Kelompok mahasiswa yang diajar dengan gaya mengajar komando secara keseluruhan

Kelompok $3=$ Kelompok mahasiswa yang memiliki motor ability tinggi secara keseluruhan

Kelompok $4=$ Kelompok mahasiswa yang memiliki motor ability rendah secara keseluruhan

Kelompok $5=$ Kelompok mahasiswa yang memiliki motor ability tinggi, diajar 


Kelompok $6=\begin{aligned} & \text { dengan gaya mengajar resiprokal } \\ & \text { Kelompok mahasiswa yang memiliki motor ability tinggi, diajar } \\ & \text { dengan gaya mengajar komando }\end{aligned}$
Kelompok $7=\begin{aligned} & \text { Kelompok mahasiswa yang memiliki motor ability rendah, diajar } \\ & \text { dengan gaya mengajar resiprokal }\end{aligned}$
Kelompok $8=\begin{aligned} & \text { Kelompok mahasiswa yang memiliki motor ability rendah, diajar } \\ & \text { dengan gaya mengajar komando }\end{aligned}$

Uji homogenitas yang digunakan dalam penelitian ini adalah uji Bartlett dengan taraf signifikansi $\alpha=0,05$. Ringkasan hasil perhitungan uji homogenitas varians masing-masing kelompok tampak pada Tabel di bawah ini.

Tabel 4. Ringkasan Hasil Perhitungan Uji Homogenitas Varians Masing-masing Kelompok Perlakuan dengan Uji Bartlett

\begin{tabular}{cccccc}
\hline Kelompok & Varians & $\begin{array}{c}\text { Varians } \\
\text { Gabungan }\end{array}$ & $\mathbf{X}^{\mathbf{2}}$ hitung & $\begin{array}{c}\mathbf{X}^{\mathbf{2}}{ }_{\text {tabel }} \\
\boldsymbol{\alpha}=\mathbf{0 , 0 5}\end{array}$ & Kesimpulan \\
\hline 1 & 2.9231 & & & & \\
2 & 7.3974 & 5.4197 & 21,895 & 7,81 & Homogen \\
3 & 6.6633 & & & & \\
4 & 4.6952 & & & & \\
\hline
\end{tabular}

Keterangan :

Kelompok $1=$ Kelompok mahasiswa yang memiliki motivasi tinggi diajar dengan gaya mengajar komando

Kelompok $2=$ Kelompok mahasiswa yang memiliki motivasi belajar tinggi diajar dengan gaya mengajar latihan

Kelompok $3=$ Kelompok mahasiswa yang memiliki motivasi belajar rendah diajar dengan gaya mengajar komando

Kelompok $4=$ Kelompok mahasiswa yang memiliki motivasi belajar rendah diajar denga gaya mengajar latihan

Dari hasil perhitungan uji homogenitas seperti tampak pada tabel di atas, didapat harga Chikuadrat sebesar $\left(\chi_{\mathrm{h}}^{2}=2,1895\right)$ untuk seluruh kelompok sampel, lebih kecil daripada Chikuadrat tabel $\left(\chi^{2 t}=7,81\right)$. Dengan demikian dapat disimpulkan bahwa sampel penelitian berasal dari populasi berdistribusi homogen.Uji homogenitas dilakukan dengan cara membandingkan antara varians terbesar dengan varians terkecil dari masing-masing kelompok.

Uji homogenitas yang digunakan dalam penelitian ini adalah uji Bartlett dengan taraf signifikansi $\alpha=0,05$. Ringkasan hasil perhitungan uji homogenitas varians masing-masing kelompok tampak pada Tabel di bawah ini. 
Tabel 3. Rangkuman Uji Homogenitas Secara Keseluruhan

\begin{tabular}{ccccc}
\hline Kelompok & Varians & $\mathbf{F}_{\mathbf{o}}$ & $\begin{array}{c}\mathbf{F}_{\mathbf{t}} \\
\boldsymbol{\alpha}=\mathbf{0 , 0 5}\end{array}$ & Kesimpulan \\
\hline $\mathbf{A}_{\mathbf{1}}$ & $\begin{array}{c}25.0816 \\
58.155\end{array}$ & 0,43 & 2,17 & Homogen \\
\hline $\mathbf{A}_{\mathbf{2}}$ & $\begin{array}{c}38.9053 \\
97.4632\end{array}$ & 0,45 & 2,17 & Homogen \\
\hline $\mathbf{B}_{\mathbf{1}}$ & 8.5444 & 0,16 & 3,18 & Homogen \\
$\mathbf{B}_{\mathbf{2}}$ & 73.3889 & & & Homogen \\
\hline $\mathbf{A}_{\mathbf{1}} \mathbf{B}_{\mathbf{1}}$ & 38.1778 & 2,01 & 3,18 & \\
$\mathbf{A}_{\mathbf{2}} \mathbf{B}_{\mathbf{1}}$ & 14.4889 & & & \\
\hline $\mathbf{A}_{\mathbf{1}} \mathbf{B}_{\mathbf{2}}$ & & & & \\
$\mathbf{A}_{\mathbf{2}} \mathbf{B}_{\mathbf{2}}$ & & & & \\
\hline
\end{tabular}

\section{Keterangan :}

$\mathbf{A}_{\mathbf{1}}=$ Kelompok mahasiswa yang diajar dengan gaya mengajar komando

$\mathbf{A}_{\mathbf{2}}=$ Kelompok mahasiswa yang diajar dengan gaya mengajar latihan

$\mathbf{B}_{\mathbf{1}}=$ Kelompok mahasiswa yang memiliki motivasi belajar tinggi secara keseluruhan

$\mathbf{B}_{2}=$ Kelompok mahasiswa yang memiliki motivasi belajar rendah secara keseluruhan

$\mathbf{A}_{\mathbf{1}} \mathbf{B}_{\mathbf{1}}=$ Kelompok mahasiswa yang memiliki motivasi belajar tinggi diajar dengan gaya mengajar komando

$\mathbf{A}_{2} \mathbf{B}_{1}=$ Kelompok mahasiswa yang memiliki motivasi belajar tinggi diajar dengan gaya mengajar latihan

$\mathbf{A}_{1} \mathbf{B}_{2}=$ Kelompok mahasiswa yang memiliki motivasi belajar rendah diajar dengan gaya mengajar komando

$\mathbf{A}_{\mathbf{2}} \mathbf{B}_{\mathbf{2}}=$ Kelompok mahasiswa yang memiliki motivasi belajar rendah diajar dengan gaya mengajar latihan.

Berdasarkan hasil perhitungan uji homogenitas varians sebagaimana terlihat pada Tabel di atas, diperoleh harga-harga $\mathrm{F}_{\text {hitung }}$ sebagai berikut: kelompok pertama $\mathrm{F}_{\text {hitung }}=$ 0,43 ; kelompok kedua $\mathrm{F}_{\text {hitung }}=0,45$; kelompok ketiga $\mathrm{F}_{\text {hitung }}=0,16$; kelompok keempat $\mathrm{F}_{\text {hitung }}=2,01$,sedangkan $\mathrm{F}_{\text {tabel }}=2,17$ dan 3,18. Dengan demikian $\mathrm{F}_{\text {hitung }}$ semua kelompok lebih kecil daripada $\mathrm{F}_{\text {tabel }}\left(\mathrm{F} 1234<\mathrm{F}_{\text {tabel }}\right)$. Kesimpulannya bahwa sampel berasal dari populasi yang homogen.

Setelah uji persyaratan analisis terpenuhi, selanjutnya dilakukan pengujian hipotesis statistic dengan menggunakan Analisis Varians (ANAVA) dua jalur, pada taraf signifikansi $\alpha=0,05$, dilanjutkan dengan uji Tukey.

Tabel 5. Rangkuman Hasil Perhitungan Analisis Varians (ANAVA) Dua jalur Data Hasil Belajar Stut Senam Lantai.

\begin{tabular}{lccccc}
\hline $\begin{array}{c}\text { SUMBER } \\
\text { VARIANS }\end{array}$ & JK & dk & RJK & $\mathbf{F}_{\text {hitung }}$ & $\begin{array}{c}\mathbf{F}_{\text {tabel }} \\
\boldsymbol{\alpha = 0 , 0 5}\end{array}$ \\
\hline Antar Kolom (A) & 672.4 & 1 & 672,4 & 207,353 & 4,11 \\
\hline Antar Baris (B) & 202.5 & 1 & 202,5 & 62,446 & 4,11 \\
\hline & & Penjaskesrek FKIP Universitas Islam Riau & 12 \\
& & & &
\end{tabular}




\begin{tabular}{lccccc} 
Interaksi AxB & 212 & 1 & 211,6 & 65,253 & 4,11 \\
\hline $\begin{array}{l}\text { Dalam Kelompok } \\
\text { (DK) }\end{array}$ & 1167,40 & 36 & - & - & - \\
\hline TOTAL & 2253,90 & 39 & - & - & - \\
\hline
\end{tabular}

Keterangan :

A = Gaya Mengajar Komando dengan Gaya Mengajar Latihan

$\mathrm{B}=$ Motivasi Belajar Tinggi dengan Motivasi Belajar Rendah

$\mathrm{AB}=$ Interaksi antara Gaya Mengajar dengan Motivasi Belajar

$\mathrm{Dk} \quad=$ Derajat Kebebasan

RJK = Rerata Jumlah Kuadrat

$\mathrm{F}_{\text {hitung }}=$ Harga $\mathrm{F}$ hitung

$\mathrm{F}_{\text {tabel }}=$ Harga $\mathrm{F}$ tabel

Ringkasan perhitungan tahap lanjut dengan teknik analisis Uji Tukey, tampak pada Tabel di bawah ini.

Tabel 6. Ringkasan Hasil Perhitungan Analisis Tahap Lanjut dengan Uji Tukey

\begin{tabular}{|c|c|c|c|c|}
\hline No & $\begin{array}{l}\text { Kelompok Yang } \\
\text { Dibandingkan }\end{array}$ & Qhitung & $\mathbf{Q}_{\text {tabel }}$ & Keterangan \\
\hline 1 & A1B1 dengan A2B1 & 39,983 & 3,63 & Signifikan \\
\hline 2 & A1B2 dengan A2B2 & 142,161 & 3,63 & Signifikan \\
\hline
\end{tabular}

Berdasarkan hasil perhitungan Analisis Varians (ANAVA) dua jalan dan Uji Tukey di atas maka dapat disimpulkan sebagai berikut :

\section{Terdapat Perbedaan Hasil Belajar Stut Antara Yang Diajar Dengan Gaya Mengajar Komando Dan Yang Diajar Dengan Gaya Mengajar Latihan Secara Keseluruhan.}

Dari hasil perhitungan analisis varians (ANAVA) diperoleh harga $F_{\text {hitung }}=20,7353$ sedangkan harga $\mathrm{F}_{\text {tabel }}$ dengan $\mathrm{dk}$ pembilang $\mathrm{V} 1$ (a-1) $(\mathrm{b}-1)=(2-1)(2-1)=1$, dk penyebut V2 ab (n-1) = 2 X $2(10-1)$, pada taraf signifikansi $\alpha=0,05$ sebesar 4,11. Dengan demikian $\mathrm{F}_{\text {hitung }}>\mathrm{F}_{\text {tabel }}\left(\mathrm{F}_{\text {hitung }}=20,7353>\mathrm{F}_{\text {tabel }}=4,11\right)$. Sehingga Ho ditolak $\left(\mathrm{F}_{0}>\mathrm{F}_{\mathrm{t}}\right)$ ini menunjukkan bahwa secara keseluruhan terdapat perbedaan hasil belajar stut secara berarti antara mahasiswa yang diajar dengan menggunakan gaya mengajar komando dan mahasiswa yang diajar dengan menggunakan gaya mengajar latihan. Secara keseluruhan kelompok yang diajar dengan menggunakan gaya mengajar komando lebih baik dibandingkan dengan kelompok yang diajar dengan menggunakan gaya mengajar latihan. Hal ini karena skor rerata kelompok gaya mengajar komando adalah $\bar{X}=74,15$ dan $S D=5,01$ sedangkan rerata skor kelompok gaya mengajar latihan adalah $\bar{X}=65,95$ dan $S D=7,63$. 


\section{Terdapat Interaksi Antara Gaya Mengajar Dan Motivasi Belajar Terhadap Hasil Belajar Stut Senam Lantai.}

Dari hasil perhitungan analisis varians (ANAVA) diperoleh harga $F_{\text {hitung }}=6,2446$ sedangkan harga $\mathrm{F}_{\text {tabel }}$ dengan $\mathrm{dk}$ pembilang V1 (a-1) $(\mathrm{b}-1)=(2-1)(2-1)=1$, dk penyebut V2 ab (n-1) = 2 X 2 (10-1), pada taraf signifikansi $\alpha=0,05$ sebesar 4,11. Dengan demikian $\mathrm{F}_{\text {hitung }}>\mathrm{F}_{\text {tabel }}\left(\mathrm{F}_{\text {hitung }}=6,2446>\mathrm{F}_{\text {tabel }}=4,11\right)$. Sehingga Ho ditolak $\left(\mathrm{F}_{0}>\mathrm{F}_{\mathrm{t}}\right)$ ini artinya terdapat pengaruh interaksi yang sangat berarti antara gaya mengajar dan motivasi belajar yang dimiliki mahasiswa terhadap hasil belajar stut senam lantai.

3. Perbedaan Hasil Belajar Stut Antara Kelompok Mahasiswa Yang Diajar Dengan Gaya Mengajar Komando Dan Yang Diajar Dengan Gaya Mengajar Latihan, Bagi Mahasiswa Yang Memiliki Motivasi Belajar Tinggi

Ditinjau dari data penelitian menggunakan uji Tukey di atas diperoleh $\mathrm{Q}_{\text {hitung }}=$ 3,9983 lebih besar dari pada $\mathrm{Q}_{\text {tabel }}=3,63$ ( $\mathrm{Q}_{\text {hitung }}=3,9983>\mathrm{Q}_{\text {tabel }}=3,63$ ) sehingga Ho ditolak $\left(\mathrm{F}_{0}>\mathrm{F}_{\mathrm{t}}\right)$, ini berarti perbedaan yang signifikan hasil belajar stut bagi mahasiswa yang memiliki motivasi belajar tinggi yang diajar dengan gaya mengajar komando dan yang diajar dengan gaya mengajar latihan. Artinya terdapat perbedaan yang sangat berarti hasil belajar stut antara mahasiswa yang diajar dengan gaya mengajar komando dan yang diajar dengan gaya mengajar latihan, bagi mahasiswa yang memiliki motivasi tinggi. Gaya mengajar komando $(\bar{X}=74,1, S D=2,92)$ lebih baik daripada gaya mengajar latihan $(\bar{X}=73,5, S D=8,57)$ bagi mahasiswa yang memiliki motivasi belajar tinggi.

\section{Perbedaan Hasil Belajar Stut Antara Kelompok Mahasiswa Yang Diajar} Dengan Gaya Mengajar Komando Dan Yang Diajar Dengan Gaya Mengajar Latihan, Bagi Mahasiswa Yang Memiliki Motivasi Beajar Rendah

Ditinjau dari data penelitian menggunakan uji Tukey di atas diperoleh $\mathrm{Q}$ hitung $=$ 14,2161 lebih besar dari pada $\mathrm{Q}_{\text {tabel }}=3,63$ ( $\mathrm{Q}$ hitung $=14,2161>\mathrm{Q}_{\text {tabel }}=3,63$ ). Sehingga Ho ditolak $(\mathrm{F} 0>\mathrm{Ft}$ ), ini berarti perbedaan yang signifikan hasil belajar stut bagi mahasiswa yang memiliki motivasi belajar rendah yang diajar dengan gaya mengajar latihan dan yang diajar dengan gaya mengajar komando. Artinya terdapat perbedaan yang sangat berarti hasil belajar stut antara mahasiswa yang diajar dengan gaya mengajar latihan dan yang diajar dengan gaya mengajar komando, bagi mahasiswa yang memiliki motivasi belajar rendah. Gaya mengajar komando $(\bar{X}=78,20, S D=6,18)$ lebih baik daripada gaya mengajar latihan $(\bar{X}=61,60, S D=3,81)$ bagi mahasiswa yang memiliki motivasi belajar rendah.

\section{KESIMPULAN}

Dari hasil pengolahan dan analisis data serta pengujian hipotesis sebagaimana telah dipaparkan pada Bab IV di atas, diperoleh beberapa kesimpulan hasil penelitian sebagai berikut:

1. Secara keseluruhan terdapat perbedaan yang berarti antara kelompok yang diajar dengan gaya mengajar komando dan yang diajar dengan gaya mengajar latihan terhadap hasil belajar stut senam lantai. Kelompok yang diajar dengan gaya mengajar komando lebih baik daripada kelompok yang diajar dengan gaya mengajar 
latihan $\left(\mathrm{F}_{\text {hitung }}=6,2446>\mathrm{F}_{\text {tabel }}=4,11\right)$. Dengan kata lain, secara keseluruhan gaya mengajar komando memberikan pengaruh yang lebih baik daripada gaya mengajar latihan terhadap hasil belajar stut senam lantai mahasiswa putera yang mengontrak mata kuliah senam lantai PJKR Universitas Siliwangi Kota Tasikmalaya. Terdapat interaksi antara gaya mengajar dengan motivasi belajar terhadap hasil belajar stut senam lantai. Hal ini terlihat dari hasil perhitungan ANAVA, diperoleh $\mathrm{F}_{\text {hitung }}=$ 6,5253 lebih besar daripada $\mathrm{F}_{\text {tabel }}=4,11$. Ini berarti bahwa hasil belajar stut dipengaruhi oleh gaya mengajar yang digunakan dan motivasi belajar, atau dengan kata lain hasil belajar stut senam lantai, selain ditentukan oleh gaya mengajar yang digunakan, juga dipengaruhi oleh tingkat motivasi belajar yang dimiliki.

2. Terdapat perbedaan yang berarti antara yang diajar dengan gaya mengajar komando dan yang diajar dengan gaya mengajar latihan bagi mahasiswa yang memiliki motivasi belajar tinggi terhadap hasil belajar stut senam lantai. Bagi mahasiswa yang memiliki motivasi belajar tinggi, diajar dengan gaya mengajar komando lebih baik daripada diajar dengan gaya mengajar latihan $\left(\mathrm{q}_{\text {hitung }}=3,99829>\mathrm{q}_{\text {tabel }}=3,63\right)$. Dengan kata lain, bagi mahasiswa yang memiliki motivasi belajar tinggi, gaya mengajar komando memberikan pengaruh yang lebih baik daripada gaya mengajar latihan terhadap hasil belajarstut senam lantai mahasiswa putera yang kontrak mata kuliah senam lantai PJKR Universitas Siliwangi Kota Tasikmalaya.

3. Terdapat perbedaan yang berarti antara yang diajar dengan gaya mengajar komando dan yang diajar dengan gaya mengajar latihan bagi mahasiswa yang memiliki motivasi belajar rendah terhadap hasil belajar stut senam lantai. Bagi mahasiswa yang memiliki motivasi belajar rendah, diajar dengan gaya mengajar komando lebih baik daripada diajar dengan gaya mengajar latihan $\left(\mathrm{q}_{\text {hitung }}=14,22>\mathrm{q}_{\text {tabel }}=3,63\right)$. Dengan kata lain, bagi mahasiswa yang memiliki motivasi belajar rendah, gaya mengajar komando memberikan pengaruh yang lebih baik daripada gaya mengajar latihan terhadap hasil belajar stut pada mahasiswa putera yang kontrak mata kuliah senam lantai PJKR Universitas Siliwangi Kota Tasikmalaya. Hasil penelitian ini memberikan implikasi terutama berkenaan dengan gaya pembelajaran untuk senam lantai khususnya pembelajaran stut dan pendidikan di perguruan tinggi pada umumnya.

a. Kesimpulan yang menyatakan terdapat perbedaan yang berarti antara kelompok yang diajar dengan gaya mengajar komando dan yang diajar dengan gaya mengajar latihan terhadap hasil belajar stut senam lantai. Gaya mengajar komando memberikan pengaruh lebih baik daripada gaya mengajar latihan terhadap hasil belajar stut senam lantai. Oleh karena itu, khususnya bagi para tenaga pengajar atau dosen olahraga menyadari bahwa pemilihan gaya mengajar dalam proses pembelajaran perlu diperhatikan. Terutama dalam pembelajaran senam lantai, pemilihan gaya mengajar harus selektif karena akan berpengaruh terhadap pencapaian tujuan yang diharapkan khususnya dalam penguasaan teknik-teknik dalam senam lantai

c. Kesimpulan yang menyatakan terdapat interaksi yang berarti antara gaya mengajar dan motivasi belajar terhadap hasil belajar stut senam lantai. Gaya mengajar yang digunakan akan memberikan pengaruh terhadap pencapaian tujuan yang diharapkan, karena dalam gaya mengajar terdapat hal-hal yang harus diperhatikan, seperti : keputusan sebelum pelaksanaan pembelajaran (pre impact), keputusan saat pelaksanaan pembelajaran (impact) dan keputusan setelah pelaksanaan 
pembelajaran (post impact). Selain gaya mengajar, motivasi belajar mahasiswa juga sangat berpengaruh terhadap tercapainya tujuan pembelajaran. Terutama dalam pembelajaran yang bersifat praktis, tinggi rendahnya motivasi belajar sangat mendukung.

d. Kesimpulan yang menyatakan terdapat perbedaan pengaruh antara gaya mengajar komando dan gaya mengajar latihan bagi kelompok mahasiswa yang memiliki motivasi belajar tinggi terhadap hasil belajar stut senam lantai. Gaya mengajar komando lebih berpengaruh terhadap hasil belajar stut dibandingkan gaya mengajar latihan bagi mahasiswa yang memiliki motivasi belajar tinggi. Motivasi belajar tinggi ternyata memberi pengaruh lebih baik terhadap hasil belajar stut untuk gaya mengajar komando. Temuan ini mengindikasikan perlunya upaya pemilihan mahasiswa peserta pembelajaran stut berdasarkan motivasi belajarnya. Pemilihan mahasiswa berdasarkan motivasi belajar tersebut digunakan sebagai pedoman untuk memilih dan menetapkan gaya mengajar yang tepat untuk masing-masing kelompok mahasiswa, agar diperoleh hasil belajar yang lebih optimal. Bagi mahasiswa yang memiliki motivasi belajar tinggi diupayakan penerapan gaya mengajar komando pada pembelajaran stut, karena sesuai dengan karakteristiknya gaya mengajar komando lebih memberikan penekanan dalam keseragaman gerak dan keselamatan dalam proses belajar juga peningkatan kedisiplinan dalam mempelajari tugas ajar dan memberi kesempatan untuk berkreatif dan memanfaatkan waktu untuk mencapai penguasaan gerak sehingga pembelajaran lebih menantang. Maka dari itu bagi mahasiswa yang memiliki motivasi belajar tinggi, gaya mengajar komando lebih baik digunakan dalam pencapaian hasil belajar stut senam lantai.

e. Kesimpulan yang menyatakan terdapat perbedaan pengaruh antara gaya mengajar komando dan gaya mengajar latihan bagi kelompok mahasiswa yang memiliki motivasi belajar rendah terhadap hasil belajar stut. Gaya mengajar komando lebih baik daripada gaya mengajar latihan terhadap hasil belajar stut bagi mahasiswa yang memiliki motivasi belajar rendah. Gaya mengajar komando lebih berpengaruh baik terhadap mahasiswa yang memiliki motivasi belajar rendah terhadap hasil belajar stut. Itu karena mahasiswa yang memiliki motivasi belajar rendah lebih bersifat pasif, malas dan kurang kreatif sehingga dibutuhkan suatu pembalajaran yang benar-benar terkontrol dan terkendali agar proses dan hasilnya bisa tercapai optimal. Gaya mengajar komando lebih cocok dan pantas bagi mahasiswa yang memiliki motivasi belajar rendah, karena karakteristik gaya ini adalah semua kendali ada pada tenaga pengajar atau dosen, mempertinggi kedisiplinan dan kepatuhan, sangat efektif dan efisien untuk waktu yang singkat, dan juga baik untuk membina keseragaman dan kekompakan.

\section{DAFTAR PUSTAKA}

Djamarah, Syaiful Bahri. 2011. Psikologi Belajar. Jakarta: PT. Rineka Cipta.

Ferducci, Frank, M. 1980. Measurement Concepts in Physical Education. St. Louis. The C.V. Mosby Company.

Hamalik, Oemar. 2008. Dasar-Dasar Pengembangan Kurikulum. Bandung: PT. Remaja Rosdakarya, 2008. 
Hidayat, Imam . 2006. Senam. Bandung : Fakultas Pendidikan Olahraga dan Kesehatan Institut Keguruan dan Ilmu Pendidikan Bandung.

Husdarta, J.S. dan Saputra, M. Yudha. 2010. Belajar dan Pembelajaran Pendidikan Jasmani dan Kesehatan. Bandung : Penerbit Dewa Ruchi.

Lutan, Rusli. 2000. Strategi Belajar Mengajar Penjaskes. Jakarta: Depdiknas, Ditjen Dikdasmen.

Mahendra, Agus. 2006. Pembelajaran Senam: Pendekatan Pola Gerak Dominan untuk Siswa SLTP. Jakarta Pusat :Direktorat Jenderal Olahraga, Depdiknas.

Mosston, Musska and Asworth, Sara. 2010. Teaching Physical Education (New York: Mac Millan College Publishing Inc.

Sugiono. 2013. Statistika untuk Penelitian. Bandung: Alfabeta.

Werner, Peter H. 2012. Teaching Children Gymnastics. United States : by Peter H. Werner, Lori H. Williams, Tina J. Hal. 